\title{
Political risk and foreign direct investment in Nigeria: New empirical evidence
}

\author{
Musa Hatim Koko ${ }^{a^{*}}$, Yatiban Aminurraasyid ${ }^{a}$ and Zengeni Knocks Tapiwa ${ }^{a}$
}

${ }^{a}$ School of International Studies, College of Law, Government and International Studies (COLGIS), 06010, Universiti Utara Malaysia, Sintok, Kedah, Malaysia

\begin{tabular}{l}
\hline C H R O N I C L E \\
\hline Article history: \\
Received September 5, 2016 \\
Received in revised format \\
September 162016 \\
Accepted November 22016 \\
Available online \\
November 42016 \\
\hline Keywords: \\
Political Risk \\
FDI \\
Nigeria
\end{tabular}
\begin{abstract}
A B S T R A C T
The positive effect of globalization has continued to impact FDI inflow to developing countries during the last decade except for the rising influence of political risk in host locations. Mixed outcomes have trailed the findings related to the studies on FDI and political risk relationship and in particular on African countries like Nigeria. This paper investigated the effect of political risk on FDI inflow to Nigeria using secondary data from 2000 to 2014 using simple linear regression. The study combined from select variables, the institutional factors with location determinants peculiar to Nigeria's risk environment. It is found that political risk holds a positive and significant association with FDI to Nigeria but not close enough to inhibit the inflow of foreign investment to the country. However, the findings provide a strong basis for policy shift in relation to security, country promotion and rebranding as well strengthening of institutions.
\end{abstract}

\section{Introduction}

The recent development in the increase in foreign direct investment (FDI) flow to developing countries is a major sign of globalization mainly driven by the efforts made in liberalizing many economies creating a near absence of trade barriers. This feat is commonly associated with investors' concern on what may befall such investments in the target locations. The world FDI performances in the last decade has been encouraging which shows how vital its role in global economic contribution is, for example although a decline was witnessed in 2014 FDI flow compared to 2013, it accounted for $40 \%$ of the world total external development finance targeting developed and transition economies according to the World Investment Report (UNCTAD, 2015), making it a primary source of capital. The $16 \%$ decline according to this report shows $\$ 1.47$ trn in 2013 as against $\$ 1.2 \operatorname{trn}$ in 2014 . The overall regional attractions of global FDI for the same period shows that developing Asia maintained a leading role as preferred destination with nearly half trillion in value $(\$ 465 \mathrm{bn})$, followed by Europe $(\$ 289 \mathrm{bn})$, Latin America and the Caribbean (\$159bn), North America (\$146bn), Africa (\$54bn) and the transition economies had \$48bn. (UNCTAD, 2015).

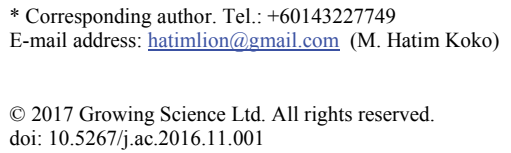


It can be deduced from the above figures quoted from the WIR that Africa receives less than $5 \%$ of the world total despite the rising rate of return on FDI in the continent since 2000 (Adams, 2009), intense promotional efforts to attract (UNCTAD, 1995) and the rising economic and emerging market potentials (UNCTAD, 2015). Additionally, this report showed that West Africa has its share of FDI fall by $10 \%$ in the same period due largely to falling prices in commodity markets, Ebola disease outbreak and regional conflicts. Nigeria's share which form part of the top five host economies in the continent stand at $\$ 4.7 \mathrm{bn}$ being $2.5 \%$ Africa's total. This report shows a $16 \%$ fall from the preceding year arising from the country's effort towards diversification into non-oil sectors (UNCTAD, 2015) which has remain in the foremost of recommendations by scholars (Kareem et al., 2012).

This marked decline in the world FDI performances as revealed by this report (UNCTAD, 2015) is a result of a fragile global economy, divestments in new investment, policy uncertainty and the rising geopolitical risks. Country risks are found to discourage FDI (Hayakawa et al., 2011) and are considered a major source of concern whenever planning for wider success whether to a local or foreign firm. Country risks according to the PRS Group are either economic, financial or political which are further categorized into six classes of economic, transfer, exchange, location, sovereign and political risks (Meldrum, 2000) commonly used by most rating services.

Literature in greater details addresses the influence of political risk on FDI inflow in developing nations. Similarly multinational firms have developed greater interest in the type and character of political risks that are likely to shape their decisions when in a host nation. This is because undeveloped and or modernizing economies have in their character political risks that create some degree of business uncertainty within the transnational political environment especially for foreign investors (Al Khattab et al., 2008) thereby making firms undertake risk assessment. We examine the character of political risk in Nigeria and its likely influence on foreign direct investment inflow using a secondary data from 2000 to 2014 . This paper contributed to literature by assessing one of the leading emerging economies in sub Saharan Africa, together informing on the true investment environment in the context of political risk associated perception to the country. Literature has long been silent on Africa's political risk and in particular Nigeria instead emphasizing the negative perceptions to potential investors. The paper proceeds with the theoretical review, methodology, results and then concludes.

\section{Theoretical background and Hypotheses}

Recent growing interest in the subject of political risk and its relationship to FDI provides a good basis seeking to evaluate its impacts and or relationships (Sottilotta, 2013) because few works offer greater significance to its effect on inward FDI flow (Goswami \& Haider, 2014) particularly on Africa. The major advantage derived by MNEs with respect to investing in different locations is the match obtained from the strategies and objectives in operations (Bartels et al., 2008), but the location benefits in themselves continue to remain relevant from the perspective of host locations (Narula, 2006). These host locations from many developing countries are greatly perceived as risky, most especially countries from the sub Saharan Africa (SSA) thereby according them less special attention in their efforts to attract FDI (Bartels et al., 2008). The risk associated with foreign investment come from the two classes in the form of macro or micro (Collier \& Hoeffler, 2002). The macro aspects of risk are seen to emanate from the sudden changes in political system affecting capital and investment through all-out war, expropriation or civil unrest; while the micro part relates to the bureaucratic or administrative overloads, corruption and the inefficiencies found in the judiciary. The perspective given in the work of Benáček et al. (2014) captured the basis for which MNEs reaction to host location characteristics take place. The study found that FDI going to receiving countries that are adjudge poor with weak and diverse institutions are found to be sensitive to political risk factors when compared to the one going to developed countries because of their long standing economies with similar institutional structure. There are different categorizations of political risk which literature have documented and continue to elicit debate. These studies seeking to classify political risk were able to maintain a connecting line in their quest to draw such basic distinctions without breaking from each other's line of conception. These 
studies include among others (Al Khattab et al., 2008; Jensen, 2008; Moosa, 2002; Schmidt, 1986). The major outstanding issue that has continued to remain unresolved in the assessment of the FDIpolitical risk relationship is the nature and character of investor preferences of countries that exhibit high market potentials but are marred by greater political risk on investment projects (Agarwal \& Ramaswami, 1992) or integrating the basic determinants of FDI with the political risk elements in order to find their effects (Busse \& Hefeker, 2005). The need to close this gap becomes evidently imperative in the current challenges to foreign capital flow and allocation to developing countries. However, studies in the past favored that high risk in developing countries serving as host countries is not considered as a hindrance to FDI inflows (van Wyk \& Lal, 2008). Other studies proving the lesser effect of political risk in inhibiting flow of FDI show that total FDI inflow is higher in risky countries when serving as a measure of country risk level of debt (Albuquerque, 2003), while long term strategic benefits are found to drive FDI into China despite high political risk (Pan, 2003).

The risk environment in Nigeria offers a unique features compared to any other African country, because the country displays the combined basic location characteristics such as large market (Cleeve, 2008), abundant natural resources (Asiedu, 2006; Dinda, 2014) and strong economic growth potentials (Ayanwale, 2007) that continue to drive international investment. Despite these favorable location benefits, Nigeria's investment climate account for greater exposure to large scale uncertainties that are in themselves major disincentives to FDI. The few research works that addressed political risk against FDI in relations to Nigeria includes (Bischoff \& Lambrechts, 2010; Frynas \& Mellahi, 2003) specifically resting their analyses on the regional assessment of the Niger-Delta risks in relation to multinational oil and gas businesses. Similarly most of the existing literature works available concentrates attention on the oil and gas associated risks, the overall political risks covering the wider business environment has only been addressed along other determinants of FDI as the case studied by Okpara et al. (2012) who found that political risk is negative and insignificant on FDI inflow to Nigeria.

We developed a framework that seek to assemble the political risk indicators peculiar to the case at hand following studies on similar subjects on Nigeria by grouping them first, comparing the variables related to risk indices and creating and bringing up a simple political risk index that can help to address and estimate the proposed model. In arriving at the select variables found fit for the present study, we considered the work of Wafure and Abu (2010) on their perspective on Niger-Delta crisis as one affecting oil production, Nwogwugwu et al. (2012) who identified common risks in Niger-Delta to include pipeline vandalism, kidnapping, illegal bunkering of oil and militant uprising and the work of Ugwuanyi and Odigbo (2012) who identified serial internal conflicts in the form of ethnic, religious and tribal inclination as another dimension of instability to the country.

The rising interest in Boko Haram uprising document a new line of risk to Nigeria involving bombings of religious sites, markets, schools, kidnapping, cattle rustling and armed robbery which we view as a another form of religious violence studied in greater literature as (Akinde \& Yusuff, 2014; Blanquart, 2012; Casimir, Nwaoga, \& Ogbozor, 2014; Eme \& Ibietan, 2012; Nicklas \& Mandela, 2014; Okoli \& Agada, 2014). The activities of the Islamic insurgents give rise to further external threats to Nigeria's land borders on the northern axis. The concern of MNCs on the level and scale of external conflict to the country host of their investment has been acknowledged by literature (Busse \& hefecker, 2005). Poverty and income gap were also found to contribute to crime in Nigeria (Inyang \& Abraham, 2013) and as well Corruption was seen to be a major obstacle for doing business in the country (NBS, 2010; The PRS Group, 2013) and past studies showed its unrelenting negative effect on FDI (Esew \& Yaroson, 2014; Mark \& Nwaiwu, 2015; Udoh \& Egwaikhide, 2008). Some studies addressed the components of risk in the oil and gas business although wider risks covering other sectors were mentioned (Bischoff \& Lambrechts, 2010; Somers-cox, 2014). There are other significant indices of importance considered of primary relevance to our model, the changes in government policy and the investment profile of the country being assessed as developed in the ICRG institutional measures. Literature support that MNEs remain cautious of the changes in policy of government (Cherian \& Perotti, 2001) and as well the timing of such changes (Cheng \& Kwan, 2000) being crucial to FDI 
attraction and or decisions. The role related to profiling investment opportunities in helping FDI flow in both developing and industrializing nations has been emphasized (Baek \& Qian, 2011) and also in explaining the differences in industry and international investment profile of nations relating to issues in location decisions (Dunning, 2001) as a matter of importance found in the eclectic paradigm. We therefore choose investment profile, changes in government policy, disputes with neighboring countries and corruption; ethnic tension, religious tension, political violence and kidnapping as common and most influential risk indices present in the Nigeria's political risk environment assembled among the diverse literature noted above. The factors reflect institutional, social and cultural considerations.

\subsection{Investment Profile}

Studies in the past have used the ICRG classification of investment profile of host nations to examine the level and extent of how payments, repatriation of profits and expropriation or viability of contracts are affected (Bandyopadhyay et al., 2013; Jakobsen \& \& Soysa, 2006; Mohamed \& Sidiropoulos, 2010). We hypothesized that investment profile of host nation is expected to favor the inflow of FDI despite the discouraging effect of political risk (H1).

\subsection{Changes in government policy}

Unstable policy changes in a business environment constitute greater political risk to foreign investment. The study conducted by Fedderke and Romm (2006) has been concerned with the impact of policy involvement in helping to drive FDI inflow to South Africa along other determinants found that policies rolled out by government are strong and direct enough to address their essence showing that government policy measures as good as they are continue to improve FDI flow to the country. We hypothesized that consistent policy will promote investment but changes and uncertainty in policy is expected to affect FDI inflows significantly (H2).

\subsection{Disputes with neighboring countries}

Research findings favors the concern of MNCs on the level and scale of internal and external conflicts to the country host of their investment by raising the economic and political instability either in form of civil wars, political violence, sanctions or full scale war (Busse \& Hefeker, 2005). It is valid to relate FDI flows to the potential effects of border conflicts by hypothesizing that host nation disputes with its neighbors can affect its FDI potentials (H3).

\subsection{Corruption}

Corruption is found to affect investment in countries where it is rampant (Everhart, 2010); creates public and or private additional non market business costs (Kurtzman et al., 2004) and may create an unattractive climate for investment depending on the type of FDI in question (Brouthers et al., 2008). Most research favored its negative effect on Nigeria and how it affects investment flow by limiting the potentials of the nation and damaging its image worldwide (Asiedu, 2006; Asiedu \& Freeman, 2009; Esew \& Yaroson, 2014; Mark \& Nwaiwu, 2015; Udoh \& Egwaikhide, 2008). Corruption being component of institutional factors is predicted to significantly affect FDI inflow (H4).

\subsection{Ethnic tension}

Ethnicity has conflict generating effect and is found to assist in determining political and economic structure of nations and societies (Alesina et al., 2002) thereby serving as a form of proxy for pressure group divisions, aimed at promoting rent-seeking and overspending, undermining public goods provision and encouraging inequality (Posner, 2004). Literature acknowledges the influence of ethnicity (and the conflicts it breeds) on growth movement of African societies when it identified that increased diversity inhibits growth especially in sub-Saharan Africa (Easterly \& Levine, 1997). Part of the explanations as to the slow growth tragedy of Africa is the issue of domestic destiny embedded 
with ethno-linguistic diversity as one of the factors affecting investment flow (Collier \& Gunning, 1999). It is predicted therefore that ethnicity and its associated features may significantly affect FDI inflow (H5).

\subsection{Religious tension}

Literature favors the principles that religion in its moderate and anti-violent forms are major origins of social order (Etzioni, 2008) and that extreme forms of beliefs begets terrorism being another form of political violence which is seen to affect capital flow in form of FDI (Filer \& Stanisic, 2012). The need to inquire further on the link between religion and violence has been suggested by scholars (Casimir et al., 2014) leading to an emerging area being referred to as 'religious violence'. Religion and its associated effect are expected to have significant effect on FDI inflow (H6).

\subsection{Political violence}

Studies shows that political violence has been found to affect FDI by decreasing the chances of the country chosen as an investment location rather than reducing the size of investment $(\mathrm{Li}, 2006)$ and findings further shows that such political violence are associated with being the product of weak institutions (Besley \& Persson, 2011). Political violence can largely affect the return on investment of multinational firms (Jensen, 2008) even though it was considered not significant enough to hinder the attraction of FDI (Edwards, 1990). Deep ethnic, tribal and religious misunderstanding and or intolerance related conflicts are common forms of violence in Nigeria (Ugwuanyi \& Odigbo, 2012). We therefore predict that political violence may have significant effect on FDI inflow $(\mathrm{H} 7)$.

\subsection{Kidnapping}

Kidnapping is primarily considered as an unplanned effect of globalization (Yun, 2007) because it is considered a major component of violent crime that is seen to affect investment across borders. Recent study by (Laverde et al., 2009) investigated the relationship between crime, uncertainty and stock return in Columbia and found that violent crimes including kidnapping affect stock market negatively. Kidnapping is becoming a booming business in Nigeria especially kidnapping for ransom rising to an unprecedented level of over 2000 cases recorded between 2009 to 2012 alone (Okoli \& Agada, 2014). The Boko Haram insurgency produced the habit of abducting foreign workers, mid-level government officials and priests (both Muslim and Christians) since 2010 (Jamestown Foundation, 2014). The Niger Delta has been the hot bed for kidnapping oil workers by militants leading to elevating kidnapping as a common crime in the region. We expect kidnapping to affect FDI inflow greatly (H8).

\section{Method}

The data reflecting the dependent variable (FDI) shows a time series pattern for the inflow to Nigeria obtained from the United Nations Conference on Trade and Development (UNCTAD) covering the period 2000-2014. The UNCTAD figures are used for their consistency and accuracy in presenting country inflow overtime. While the data for the independent variables featuring the political risk indicators were obtained from sources peculiar to the index as it covers the country being assessed. The risk indicators as earlier mentioned are change in government policy (CGP), Kidnapping (Kid), Investment Profile (InvtP), Ethnic Tension (EthT), Religious Tension (RelT), Political Violence (PolV), Corruption (CORR), and Dispute with Neighboring Countries (DNC). KID data are carefully obtained from Nigeria Police, Red24 and the Global Data of events after screening and harmonized to arrive at one near comprehensive and reliable. PolV data is from the ITERATE covering 1995-2012 and 2013-2016, and that of the Armed Conflicts (1946-2014) provided by the Uppsala conflict data program (UCDP) compared and used. These were used in the past to assess PolV (Li, 2006; Powers \& Choi, 2012). The variable DNC is proxied by external conflict involving conflicts across Nigerian borders on both the northern and southern borders. The datasets for DNC, InvtP, EthT, RelT and CORR are obtained from the ICRG for its wider acclaim in its traditional form of country wide standing. 
Our study differs with the past studies in that the use of entire political risk indicators in assessing country political risk, wherein here we used selected and peculiar indices to the target environment. We find for example the use of military in politics and democratic accountability to be in conflict with one another and cannot be assembled in one model, particularly in the angle of time period for the study, location and condition for which the assessment takes place. Our model follow the pattern of previous studies in assessing risk impact of location towards repelling FDI except in taking account of the political risk indices with strong peculiar nature to the study area. We specify the following model for estimation;

$$
F D I t=\beta_{0}+\beta_{1} C G P t+\beta_{2} K I D t+\beta_{3} I n v t P t+\beta_{4} D N C t+\beta_{5} \operatorname{RelTt}+\beta_{6} E t h T t+\beta_{7} \text { PolVt }+\beta_{8} C O R R t+\varepsilon t
$$

where; $\mathrm{FDI}=$ foreign direct investment; $\mathrm{CGP}=$ changes in government policy; $\mathrm{KID}=$ kidnapping; InvtP= investment profile; $\mathrm{DNC}=$ disputes with neighboring countries; $\mathrm{RelT}=$ religious tension; $\mathrm{EthT}=$ ethnic tension; $\mathrm{PolV}=$ political violence $\mathrm{CORR}=$ corruption; $\mathrm{B}=$ beta is constant; $\mathrm{t}=$ time, and $\varepsilon=$ error term.

\section{Results}

Table 1 shows the correlation analysis between political risk indices and FDI. The findings from the results establish positive association between FDI, KID, and PolV at significant levels being components of high crimes in Nigerian society. For the institutional variables, a negative association between FDI and DNC at significant level is observed. InvtP, EthT, RelT and CORR are positive and significant. Although, the level of association between all the institutional variables is observed to be higher, this could be connected to the degree of weak institutions generally found in developing countries as most studies found (Busse \& Hefeker, 2005; Esew \& Yaroson, 2014; Jensen, 2008).

\section{Table 1}

Correlation Matrix

\begin{tabular}{crccrrrrr}
\hline & \multicolumn{1}{c}{ FDI } & KID & InvtP & DNC & RelT & EthT & PolV & CORR \\
\hline FDI & 1 & & & & & & \\
KID & 0.246 & 1 & & & & & \\
InvtP & 0.8244 & 0.4733 & 1 & & & & \\
DNC & -0.8734 & -0.4156 & -0.82 & 1 & & & \\
RelT & 0.4701 & 0.0585 & 0.2386 & -0.6247 & 1 & & \\
EthT & 0.6484 & 0.3089 & 0.6431 & -0.8638 & 0.7857 & 0.1838 & 1 \\
PolV & 0.1148 & 0.8485 & 0.4159 & -0.314 & -0.0561 & 0.7213 & 0.3286 & 1 \\
CORR & 0.9104 & 0.4465 & 0.9065 & -0.8836 & 0.542 & 0.7213 \\
\hline
\end{tabular}

While conducting the preliminary tests, InvtP has been observed to exhibit the features of being collinear leading to it being dropped as recommended by Kennedy (2008). To proceed therefore with the estimation, centering was conducted at this stage following the studies of others (Disatnik \& Sivan, 2014; Smith \& Sasaki, 1979). Further to this is the removal of CGP as a component of the estimation due to the assumption that policy changes were adjudge stable throughout the period of the study and the direction of a past study point to the fact that government policies have greater effects but are sometimes found not to have any impact as source of political risk (Globerman \& Shapiro, 1999).

\subsection{Regression Results}

Table 2 highlights the model as regressed in testing the hypotheses.

4.1.1 KID has positive and significant effect on FDI indicating its ability to influence its outcome to Nigeria at $10 \%$ level. Although studies in the past found that kidnapping does not affect investment flow (Barros, 2003; Pshisva \& Suarez, 2006), the effect observed here also point to less influence on FDI indicating that we cannot reject the hypothesis (H8) due to rising crime in that direction.

4.1.2 The effect of RelT is positive at $1 \%$ significant level indicating that our finding is consistent with the previous work of (Busse \& Hefecker, 2005) thereby lending support to (Dolansky \& Alon, 
2008) especially when viewed in the context of wider diversity of the country and the size of the country's economy. The result from the analysis provides the acceptance of the hypothesis (H6) although positive; it is weak to support the assumption since a small fraction can be attracted as past studies show.

4.1.3 The rising effect of cross border conflicts represented by DNC appear negative and significant at $1 \%$ level close enough to affect inflow of FDI to Nigeria, supporting our assumption. This finding lend support to the work of (Busse \& Hefeker, 2005). This shows that there is a relationship between cross border conflicts witness on both the northern borders by the dreaded Boko Haram group and on the South by the Niger Delta militants on the seas of the gulf of Guinea or the Cameroons and FDI inflow lending support to our hypothesis (H3).

4.1.4 A significant and negative effect from EthT is found on FDI inflow also at 1\% level signifying ethnicity in Nigeria has the potency of reducing the inflow of FDI thereby supporting our hypothesis and lending further support to the findings of past studies (Collier \& Gunning, 1999).

4.1.5 PolV is negative and significant on FDI at 1\% level indicating that not all forms of political violence affect the size or flow of FDI lending support to earlier works (Edwards, 1990; Li, 2006) indicating that our assumption here cannot stand for $(\mathrm{H} 7)$.

4.1.6 CORR is found to positively and significantly affect FDI although at an almost no effect on investment flow (also at 1\%) which finding is consistent with similar outcomes (Everhart, 2010; Habib \& Zurawicki, 2002), giving support to our earlier claim for (H4) although in a small fraction of impact.

Table 2

Results of Estimation for FDI and Political Risk Indicators

\begin{tabular}{|c|c|c|c|}
\hline Var & $(1)$ & (2) & (3) \\
\hline & Model 1 & Serial correction & Robust \\
\hline \multirow[t]{2}{*}{ KID } & $0.000183^{*}$ & -1.0000053 & $0.000183^{*}$ \\
\hline & $(0.000109)$ & $(7.95 \mathrm{e}-05)$ & $(0.000118)$ \\
\hline \multirow[t]{2}{*}{$\overline{\mathrm{DNC}}$} & $-0.631^{* * *}$ & $-0.512^{* * * *}$ & $-0.631^{* * *}$ \\
\hline & $(0.118)$ & $(0.114)$ & $(0.117)$ \\
\hline \multirow[t]{2}{*}{ RelT } & $0.260^{* * * *}$ & -0.153 & $0.260^{* * * *}$ \\
\hline & $(0.0841)$ & $(0.152)$ & $(0.0873)$ \\
\hline \multirow[t]{2}{*}{ EthT } & $-1.093^{* * * *}$ & $-0.452^{* *}$ & $-1.093^{* * * *}$ \\
\hline & $(0.212)$ & $(0.179)$ & $(0.149)$ \\
\hline \multirow[t]{2}{*}{ PolV } & $-0.00262^{* * * *}$ & $-0.00216^{* * *}$ & $-0.00262^{* * * *}$ \\
\hline & $(0.000714)$ & $(0.000556)$ & $(0.000571)$ \\
\hline \multirow[t]{2}{*}{$\overline{\text { CORR }}$} & $2.043^{* * * *}$ & $1.734^{* * * *}$ & $2.043^{* * * * *}$ \\
\hline & $(0.195)$ & $(0.252)$ & $(0.250)$ \\
\hline \multirow[t]{2}{*}{ Constant } & $13.51^{* * * * *}$ & $12.39^{* * * *}$ & $13.51^{* * * * *}$ \\
\hline & (1.601) & (1.483) & (1.555) \\
\hline Observations & 57 & 57 & 57 \\
\hline R-squared & 0.951 & 0.727 & 0.951 \\
\hline
\end{tabular}

The relevant cases presented above shows the dominating but balanced effect of political risk on FDI inflow to Nigeria in contrast to the work of (Okpara et al., 2012) who found that political risk has negative and insignificant influence on FDI to Nigeria.

\section{Conclusion}

The position above aimed to explain the nature of FDI-political risk relationship reflects very much on the influence of institutional factors such as corruption, ethnicity and religion and as well location variables of risk associated impact like kidnapping, political violence and cross border conflicts capable of instigating disputes with neighboring nations as those combining to wield an approximate influence in determining foreign investment inflow to Nigeria. On average, Political risk is found to have a positive and significant influence on FDI inflow to Nigeria giving support to early theories on location decision and empirical literature. However, this rising effect is not too close to inhibit foreign investment inflow because the country parades the best attractive location factors in terms of market size (Ajayi, 2006; Obadan, 1982; Wafure \& Abu, 2010) and natural resource abundance (Asiedu, 2006; Dinda, 2014) and as well economic growth potentials (Ayanwale, 2007) being of primary considerations in MNEs location decisions. Further to this is the compensation benefits associated with 
higher risk locations in terms of investment returns (Overseas Development Institution, 1997). We cannot relate the influence of location factors as primary determinants of FDI in helping to mitigate the effect of political risk on FDI inflows such as market size, natural endowments or labour availability; future studies should set out a new agenda in attending to these issues. The sample used is considered small and therefore when expanded may change the outcome that may lead to new information. Relevant policy implication of these findings revolved round the need for government to strengthen its security and intelligence agencies towards proactive measures aimed at curbing crimes, strengthening government institutions in fighting corruption, intolerance (religious and ethnic) and cross border conflicts. The risk perception on Nigeria requires the efforts of government and stakeholders in investment promotion and country rebranding to help in attracting and informing potential investors the true position of the country's investment environment.

\section{References}

Adams, S. (2009). Can foreign direct investment (FDI) help to promote growth in Africa? African Journal of Business Management, 3, 178-183.

Agarwal, S., \& Ramaswami, S. N. (1992). Choice of foreign market entry mode: impact of ownership,location and internalisation factors. Journal of International Business Studies, 23(1), 1-27.

Ajayi, S. I. (2006). The determinants of foreign direct investment in Africa: A survey of the evidence. African Economic Research Consortium (pp. 1-244).

Akinde, M. A., \& Yusuff, M. A. (2014). Ineffective national security administration : The implication on foreign direct investment ( FDI ) in Nigeria. Research Journal of Finance and Accounting, 5(10), 1-10.

Al Khattab, A., Anchor, J., \& Davies, E. M. M. (2008). The institutionalisation of political risk assessment (IPRA) in Jordanian international firms. International Business Review, 17(6), 688-702.

Albuquerque, R. (2003). The composition of international capital flows: Risk sharing through foreign direct investment. Journal of International Economics, 61(2), 353-383.

Alesina, A., Arnaud, D., Easterly, W., Kurlat, S., \& Wacziarg, R. (2002). Fractionalization (No. 1959). HIER working paper.

Asiedu, E. (2006). Foreign Direct Investment in Africa: The role of natural resources, market size, government policy, institutions and political instability. The World Economy, 29(1), 63-77.

Asiedu, E., \& Freeman, J. (2009). The effect of corruption on investment growth: evidence from firms in Latin America, sub-Saharan Africa, and transition countries. Review of Development Economics, 13(2), 1-15.

Ayanwale, A. B. (2007). FDI and economic growth: evidence from Nigeria (No. 165) AERC working paper. Nairobi.

Baek, K., \& Qian, X. (2011). An analysis on political risks and the flow of foreign direct investment in developing and industrialized economies. Economics, Management and Financial Markets, 6(4), 60-91.

Bandyopadhyay, S., Sandler, T., \& Younas, J. (2013). Foreign direct investment, aid, and terrorism. Oxford Economic Papers, 66(1), 25-50.

Barros, C. P. (2003). An intervention analysis of terrorism: The spanish ETA case. Defence and Peace Economics, 14(6), 401-412.

Bartels, F. L., Kratzsch, S., \& Eicher, M. (2008). Foreign Direct Investment in Sub-Saharan Africa: Determinants and Location Decisions, UNIDO working paper (No. 08).

Benáček, V., Lenihan, H., Andreosso-O’Callaghan, B., Michalíková, E., \& Kan, D. (2014). Political risk, institutions and foreign direct investment: how do they relate in various European countries? The World Economy, 37(5), 625-653.

Besley, T., \& Persson, T. (2011). The logic of political violence. The Quarterly Journal of Economics, 126(3), $1-62$.

Bischoff, E., \& Lambrechts, D. (2010). The regional impact of political risk: The conflict in the Niger Delta and the political risk of the Gulf of Guinea. Strategic Review for Southern Africa.

Blanquart, G. (2012). Boko Haram: terrorist organization , freedom fighters or religious fanatics? An analysis of Boko Haram within Nigeria, an Australian perspective and the need for counter terrorism responses that involves prescribing them as a terrorist organisation, Research Online

Brouthers, L. E., Gao, Y., \& Mcnicol, J. P. (2008). Corruption and market attractiveness influences on different types of FDI. Strategic Management Journal, 29, 1-9.

Busse, M., \& Hefeker, C. (2005). Political risk, institutions and foreign direct investment, HWWA working paper (No. 315). Hamburg. 
Casimir, A., Nwaoga, C. T., \& Ogbozor, R. F. C. (2014). Religion, violence, poverty and underdevelopment in West Africa: issues and challenges of Boko Haram phenomenon in Nigeria. Open Journal of Philosophy, $4(1), 1-9$.

Cheng, L. K., \& Kwan, Y. K. (2000). What are the determinants of the location of foreign direct investment? The Chinese experience. Journal of International Economics, 51(2), 379-400.

Cherian, J., \& Perotti, E. (2001). Option pricing and foreign investment under political risk. Journal of International Economics, 55(2), 359-377.

Collier, P., \& Gunning, J. W. (1999). Why has Africa grown slowly? The Journal of Economics Perspectives, 13(3), 3-22.

Collier, P., \& Hoeffler, A. (2002). On the incidence of civil war in Africa. The Journal of Conflict Resolutions, $46(1), 13-28$.

Dinda, S. (2014). Natural resources determining FDI in Nigeria: an empirical investigation. International Journal of Research in Business and Social Science ., 3(1), 75-88.

Disatnik, D., \& Sivan, L. (2014). The multicollinearity illusion in moderated regression analysis. Marketing Letters, 27(2), 403-408.

Dolansky, E., \& Alon, I. (2008). Religious freedom, religious diversity and Japanese foreign direct investment. Research in International Business and Finance, 22(1), 22-39.

Dunning, J. H. (2001). The eclectic (OLI) paradigm of international production: past, present and future. International Journal of the Economics of Business, 8(2), 173-190.

Easterly, W., \& Levine, R. (1997). Africa' s growth tragedy: policies and ethnic Divisions. The Quarterly Journal of Economics, 112(4), 1203-1250.

Edwards, S. (1990). Capital Flows, Foreign Direct Investment, and Debt-Equity Swaps in Developing Countries (No. 3497). NBER Workng paper. Cambridge.

Eme, O. I., \& Ibietan, J. (2012). The cost of Boko Haram activities in Nigeria. Arabian Journal of Business and Management Review(OMAN Chapter), 2(2), 10-32.

Esew, N. G., \& Yaroson, E. (2014). Institutional quality and foreign direct investment (FDI) in Nigeria: a prognosis \n. IOSR Journal Of Humanities And Social Science (IOSR-JHSS), 19(6), 37-45.

Etzioni, A. (2008). Religion and Social Order. Policy Review, (May), 1-25.

Everhart, S. S. (2010). The resource curse and private investment: a theoretical model of the impact of corruption. Education, Business and Society: Contemporary Middle Eastern Issues, 3(2), 117-135.

Fedderke, J. W., \& Romm, A.T. (2006). Growth impact and determinants of foreign direct investment into South Africa, 1956-2003. Economic Modelling, 23(5), 738-760.

Filer, R., \& Stanisic, D. (2012). The Effect of Terrorist Incidents on Capital Flows (Monetary policy and International finance No. 3998). Review of Development Economics.

Frynas, J. G., \& Mellahi, K. (2003). Political risks as firm-specific (Dis)advantages: Evidence on transnational oil firms in Nigeria. Thunderbird International Business Review, 45(5), 541-565.

Globerman, S., \& Shapiro, D. M. (1999). The impact of government policies on foreign direct nvestment: The Canadian experience. Journal of International Business Studies, 30(3), 513-532.

Goswami, G. G., \& Haider, S. (2014). Does political risk deter FDI inflow?: An analytical approach using panel data and factor analysis. Journal of Economic Studies, 41(2), 233-252.

Habib, M., \& Zurawicki, L. (2002). Corruption and foreign direct investment. Journal of International Business Studies, 33(2), 291-307.

Inyang, J. D., \& Abraham, U. E. (2013). The social problem of kidnapping and its implications on the socioeconomic development of Nigeria:A study of Uyo metropolis. Mediterranean Journal of Social Sciences, 4(6), 531-544.

Jakobsen, J., \& \& Soysa, I. (2006). Do foreign investors punish democracy ? Theory and empirics , 1984 - 2001. Kyklos, 59(3), 383-410.

Jensen, N. (2008). Political risk, democratic institutions, and foreign direct investment. The Journal of Politics, $70(4), 1-14$.

Kareem, D. S., Kari, F., Alam, G. M., Chukwu, M. G. O., \& David, M. O. (2012). Foreign direct investment into oil sector and economic growth in Nigeria. The International Journal of Applied Economics and Finance, 6(4), 127-135.

Kennedy, P. (2008). A Guide to Econometrics (6th ed.). Blackwell Publishing, MA.

Kurtzman, J., Yago, G., \& Phumiwasana, T. (2004). The global costs of opacity. MIT Sloan Management Review, $46(1), 1-10$.

Laverde, J. C. F., Varua, M. E., \& Garces-Ozanne, A. (2009). Understanding crime, political uncertainty and stock market returns: A case study of the Colombian stock market. World Economics, 10(2), 109-116. 
Li, Q. (2006). Political violence and foreign direct investment. Research in Global Strategic Management, 12, 231-255.

Mark, J., \& Nwaiwu, J. N. (2015). Impact of political environment on business performance of multinational companies in Nigeria. African Research Review, 9(3), 1-10.

Meldrum, D. H. (2000). Country risk and foreign direct investment. Business Economics, 35(1), 33-40.

Mohamed, S., \& Sidiropoulos, M. (2010). Another look at the determinants of foreign direct investment in MENA countries: an empirical investigation. Journal of Economic Development, 35(2), 75-95.

Moosa, I. A. (2002). Foreign direct investment: theory, evidence, and practice. Palgrave New york

Narula, R. (2006). Globalization, new ecologies, new zoologies, and the purported death of the eclectic paradigm. Asia Pacific Journal of Management, 23, 143-151.

National Bureau of Statistics (2010). The Review of the Nigerian Economy. Abuja.

Nicklas, J., \& Mandela, L. (2014). The Rise of Boko Haram and its Economic Implications. Student Center for African Research and Resolutions.

Nwogwugwu, N., Alao, O. E., \& Egwuonwu, C. (2012). Militancy and insecurity in the Niger Delta: impact on the inflow of foreign direct investment to Nigeria. Kuwait Chapter of Arabian Journal of Businees and Management Review, 2(1), 23-37.

Obadan, M. I. (1982). Direct foreign investment in Nigeria: An empirical analysis. African Studies Review, 25(1), 1-16.

Okoli, A. C., \& Agada, F. T. (2014). Kidnapping and national security in Nigeria. Research on Humanities and Social Sciences, 4(6), 137-146.

Okpara, G. C., Ajuka, F. N., \& Nwaoha, W. C. (2012). An Error Correction Model Analysis of the Determinant of Foreign Direct Investment: Evidence from Nigeria. MPRA working paper (No. 36676). Muenchen.

Overseas Development Institution. (1997). Political Risk and Foreign Direct Investment.

Pan, Y. (2003). The inflow of foreign direct investment to China: The impact of country-specific factors. Journal of Business Research, 56(10), 829-833.

Posner, D. N. (2004). Measuring ethnic fractionalization in Africa. American Journal of Political Science, 48(4), 849-863.

Powers, M., \& Choi, S.W. (2012). Does transnational terrorism reduce foreign direct investment? Businessrelated versus non-business-related terrorism. Journal of Peace Research, 49(3), 407-422.

Pshisva, R., \& Suarez, G. A. (2006). "Captive Markets": The impact of kidnappings on corporate investment in Colombia. Coyuntura Economica, 36(1), 1-36

Schmidt, D. A. (1986). Analyzing political risk. Business Horizons, 29(4), 43-50.

Smith, K. W., \& Sasaki, M. S. (1979). Decreasing multicollinearity: A method for models with multiplicative functions. Sociological Methods and Research, 8(I), 35-56.

Somers-cox, T. J. (2014). Political Risk in the Oil and Gas Industry in Emerging Markets : A comparative study of Nigeria and Mexico. Master thesis University of Stellenbosch.

Sottilotta, C. E. (2013). Political Risk : Concepts, definitions, challenges, LUISS SOG (No. 6). Rome.

The PRS Group. (2013). Nigeria Country Report (Vol. 1). New York.

Udoh, E., \& Egwaikhide, F. O. (2008). Exchange rate volatility, inflation uncertainty and foreign direct investment in Nigeria. Botswana Journal of Economics, 5(7), 14-31.

Ugwuanyi, U., \& Odigbo, B. (2012). Public relations strategies for managing religious , ethnic and social conflicts for the promotion of foreign direct investment ( FDI ) and development in Nigeria. European Journal of Business and Management, 4(17), 40-52.

UNCTAD. (2015). United Nations Conference on Trade and Development World Investement Report 2015. Geneva.

van Wyk, J., \& Lal, A. K. (2008). Risk and FDI flows to developing countries. South African Journal of Economic and Management Science, 11(4), 261-262.

Wafure, O. G., \& Abu, N. (2010). Determinants of foreign direct investment in Nigeria: An empirical analysis. Global Journal of Human Social Science, 10(1), 26-34.

Yun, M. (2007). Implications of global terrorist hostage-taking and kidnapping. Korea Journal of Defense Analysis, 19(2).

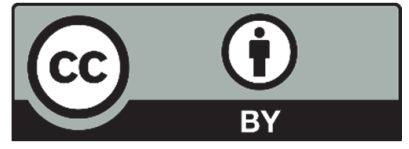

(C) 2016 by the authors; licensee Growing Science, Canada. This is an open access article distributed under the terms and conditions of the Creative Commons Attribution (CC-BY) license (http://creativecommons.org/licenses/by/4.0/). 